\title{
Saccharopolyspora phatthalungensis sp. nov., isolated from rhizosphere soil of Hevea brasiliensis
} Correspondence
Kannika Duangmal
fscikkd@ku.ac.th or
kannikaduangmal@hotmail.com

\author{
Kannika Duangmal, ${ }^{1}$ Ratchanee Mingma, ${ }^{1}$ Arinthip Thamchaipenet, ${ }^{2}$ \\ Atsuko Matsumoto ${ }^{3}$ and Yoko Takahashi ${ }^{3}$ \\ ${ }^{1}$ Department of Microbiology, Faculty of Science, Kasetsart University, Chatuchak, Bangkok 10900, \\ Thailand \\ ${ }^{2}$ Department of Genetics, Faculty of Science, Kasetsart University, Chatuchak, Bangkok 10900, \\ Thailand \\ ${ }^{3}$ Kitasato Institute for Life Sciences, Kitasato University, 5-9-1 Shirokane, Minato-ku, \\ Tokyo 108-8641, Japan
}

The genus Saccharopolyspora was first erected by Lacey \& Goodfellow (1975) with the description of Saccharopolyspora hirsuta as the type species. At the time of writing, the genus comprises 16 recognized species, namely Saccharopolyspora antimicrobica (Yuan et al., 2008), S. cebuensis (PimentelElardo et al., 2008), S. erythraea (Labeda, 1987), S. flava (Lu et al., 2001), S. gregorii (Goodfellow et al., 1989), S. halophila (Tang et al., 2009), S. hirsuta (Lacey \& Goodfellow, 1975), S. hordei (Goodfellow et al., 1989), S. jiangxiensis (Zhang et al., 2009), S. rectivirgula (Korn-Wendisch et al., 1989), S. rosea (Yassin, 2009), S. shandongensis (Zhang et al., 2008), S. spinosa (Mertz \& Yao, 1990), S. spinosporotrichia (Zhou et al., 1998), S. taberi (Labeda, 1987; Korn-Wendisch et al., 1989) and S. thermophila (Lu et al., 2001). Most species of the genus were isolated from soil samples, but S. gregorii and S. hordi were isolated from fodder (Goodfellow et al., 1989),

The GenBank/EMBL/DDBJ accession number for the 16S rRNA gene sequence of strain SR8.15 $15^{\top}$ is GQ381309.
S. cebuensis from a marine sponge (Pimentel-Elardo et al., 2008) and S. halophila from a saline lake (Tang et al., 2009). The most recently described member, $S$. rosea, was isolated from a patient with bronchial carcinoma (Yassin, 2009). Representatives of the genus Saccharopolyspora form a distinct phyletic line within the evolutionary radiation encompassing the family Pseudonocardiaceae and can be distinguished based on a combination of biochemical, morphological and physiological properties (Embley, 1992).

During the course of a programme of isolation of actinomycetes from rhizosphere soil of rubber trees (Hevea brasiliensis) in Phatthalung Province, Thailand, strain SR8.15 ${ }^{\mathrm{T}}$ was isolated by using the dilution plating method on starch casein agar plates (Küster \& Williams, 1964) supplemented with ketoconazole and nalidixic acid as antifungal and antibacterial agents, respectively. The plates, which had been seeded with soil suspension, were incubated at $28{ }^{\circ} \mathrm{C}$ for 14 days. One colony was isolated 
and purified on glucose yeast extract (GYE) agar [containing $1.0 \%(\mathrm{w} / \mathrm{v})$ glucose, $1 \%(\mathrm{w} / \mathrm{v})$ yeast extract and $1.5 \%$ (w/v) agar]. The pure culture was maintained as a $20 \%$ glycerol suspension at $-20{ }^{\circ} \mathrm{C}$ or as lyophilized cells for long-term preservation. S. shandongensis JCM $14614^{\mathrm{T}}$ and S. spinosa JCM $9375^{\mathrm{T}}$ were used as reference strains.

The cultural characteristics of strain $\mathrm{SR} 8.15^{\mathrm{T}}$ were examined on International Streptomyces Project (ISP) media 1-7 (Shirling \& Gottlieb, 1966) and GYE agar. The colour of mycelium and soluble pigment was determined by comparing them with colour chips from the Color Harmony Manual (Jacobson et al., 1958). Morphological characteristics were observed by light microscopy and scanning electron microscopy (JEOL-JSM 5600 LV) using 14-day-old cultures grown on GYE agar and ISP medium 3. Acid production from carbohydrates was determined by using the media and methods described by Gordon et al. (1974). Activity profiles of 19 enzymes were tested by using the API ZYM system (bioMérieux). Urease activity was determined based on a colour change on urea agar (Gordon et al., 1974). The temperature range for growth was determined on ISP medium 2 (Shirling \& Gottlieb, 1966) by using a temperature gradient incubator (Tokyo Kagaku Sangyo). The production of hydrogen sulfide was detected by using lead acetate strips. Hydrolysis of casein and gelatin and reduction of nitrate were examined according to the methods of Gordon \& Mihm (1957). Production of melanoid pigment was determined according to Shirling \& Gottlieb (1966). NaCl tolerance was studied on ISP medium 2 containing $\mathrm{NaCl}$ at final concentrations of $1-12 \%(\mathrm{w} / \mathrm{v})$ (at intervals of $1.0 \%)$.

To analyse chemotaxonomic markers, cell biomass was obtained by growing strain SR8.15 $5^{\mathrm{T}}$ in GYE broth in shake flasks for 3 days at $28{ }^{\circ} \mathrm{C}$. The resultant cells were washed three times in distilled water and freeze-dried. Standard procedures were used to determine the isomers of diaminopimelic acid (Hasegawa et al., 1983). The acyl type of the cell wall was analysed according to the method of Uchida \& Aida (1984). Whole-cell sugars were analysed according to the method of Becker et al. (1965). Polar lipids were examined by TLC by using the method of Minnikin et al. (1977). Menaquinones were extracted and purified by the method of Collins et al. (1977), and isoprene units were subsequently analysed by LC/MS (JMST100LP; JEOL) with a PEGASIL ODS column $(2 \phi \times$ $50 \mathrm{~mm}$ ) by using methanol:2-propanol $(7: 3)$. Mycolic acids were detected by TLC according to the method of Tomiyasu (1982). The G+C content of the DNA was determined by HPLC according to the method of Tamaoka \& Komagata (1984). Analysis of the fatty acids in cells grown in GYE broth at $28{ }^{\circ} \mathrm{C}$ for 3 days was performed according to the procedures of the Sherlock Microbial Identification System (Microbial ID).

The total DNA of strain SR8.15 ${ }^{\mathrm{T}}$ was extracted and purified following the method of Kieser et al. (2000). The 16S rRNA gene was amplified as described by Duangmal et al. (2005).
The PCR products were purified and sequenced (Macrogen) by using universal primers (Lane, 1991). The almostcomplete 16S rRNA gene sequence of strain SR8.15 (1448 bp) was aligned with corresponding sequences of representatives of the genus Saccharopolyspora, retrieved from the GenBank database, by using the CLUSTAL $x$ (Thompson et al., 1997) and PHYDIT (http://plaza.snu.ac. $\mathrm{kr} / \sim \mathrm{jchun} / \mathrm{phydit} /$ ) programs. Phylogenetic trees were inferred by the least-squares (Fitch \& Margoliash, 1967), maximum-parsimony (Kluge \& Farris, 1969) and neighbour-joining (Saitou \& Nei, 1987) methods within the PHYLIP suite of programs (Felsenstein, 1993). The resultant tree topologies were evaluated by using bootstrap analyses (Felsenstein, 1985) based on 1000 resampled datasets of the SEQBOOT and CONSENSE options from the PHYLIP package. The resultant phylogenetic trees were viewed by using the TreeView program (Page, 1996).

Strain SR8. $15^{\mathrm{T}}$ was a Gram-positive, aerobic, filamentous actinobacterium. Good growth developed on ISP medium 1, ISP medium 2 and GYE agar with white aerial mycelium and yellowish-brown substrate mycelium after 14 days at $28{ }^{\circ} \mathrm{C}$. Moderate growth occurred on ISP media 3, 6 and 7. Poor growth was observed on ISP media 4 and 5 . Brownish-black soluble pigment was produced on ISP medium 2. Chains of oval spores with spiny surfaces were observed on GYE agar (Fig. 1).

Phylogenetic analysis based on 16S rRNA gene sequences indicated that strain SR8. $15^{\mathrm{T}}$ forms a distinct cluster with members of the genus Saccharopolyspora (Fig. 2). High levels of 16S rRNA gene sequence similarity were found between strain SR8.15 ${ }^{\mathrm{T}}$ and its nearest neighbours, $S$. shandongensis CGMCC $4.3530^{\mathrm{T}}(98.9 \%)$ corresponding to $16 \mathrm{nt}$ differences over 1417 positions, and S. spinisa DSM $44228^{\mathrm{T}}(98.5 \%)$ corresponding to $21 \mathrm{nt}$ differences over 1399 positions. DNA-DNA relatedness studies provide a reliable way of distinguishing between representatives of

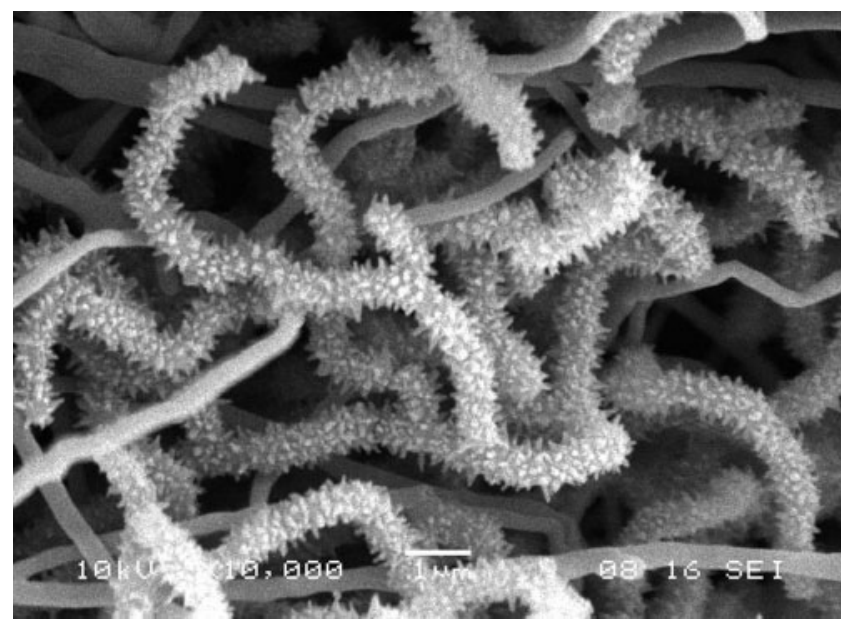

Fig. 1. Scanning electron micrograph of cells of strain SR8.15 grown on GYE agar for 14 days at $28^{\circ} \mathrm{C}$. Bar, $1 \mu \mathrm{m}$. 
0.02 substitutions/site

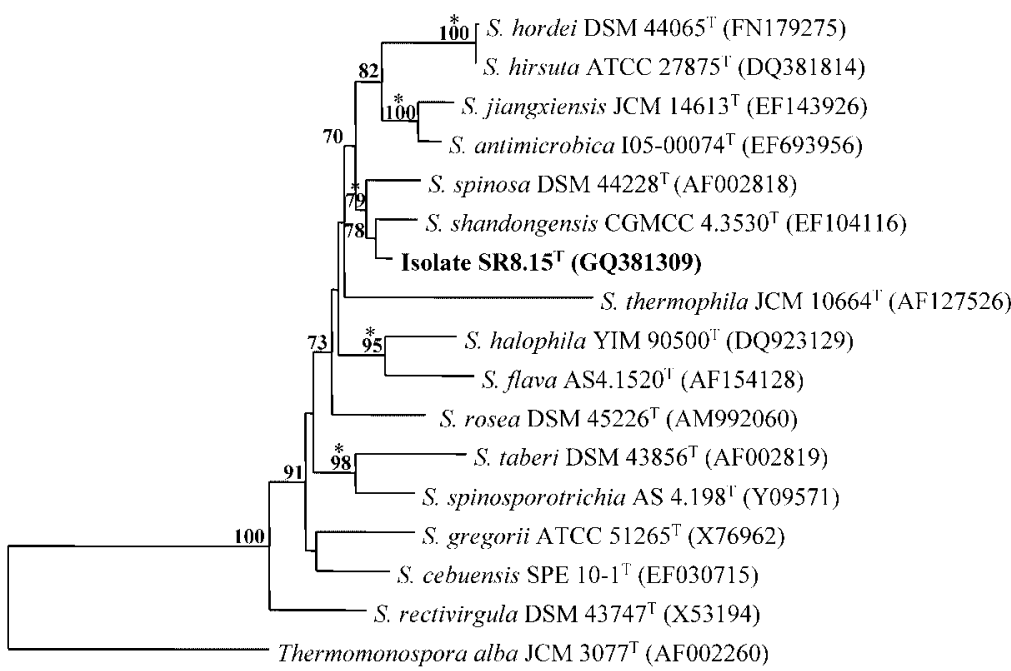

Fig. 2. Neighbour-joining tree derived from 16S rRNA gene sequences showing the relationship between strain $\mathrm{SR} 8.15^{\mathrm{T}}$ and members of the genus Saccharopolyspora. Asterisks indicate branches of the tree that were also found by using the least-squares (Fitch \& Margoliash, 1967) and maximumparsimony (Kluge \& Farris, 1969) tree-making algorithms. Numbers at nodes indicate the percentage bootstrap support from an analysis of 1000 resampled datasets. Bar, 0.02 substitutions per site.

species that share high 16S rRNA gene sequence similarity (Stackebrandt \& Ebers, 2006). Mean levels of DNA-DNA relatedness between strain $\mathrm{SR} 8.15^{\mathrm{T}}$ and $S$. shandongensis JCM $14614^{\mathrm{T}}$ and S. spinosa JCM $9375^{\mathrm{T}}$ were 45.7 and $37.7 \%$, respectively, values well below the $70 \%$ cut-off point recommended by Wayne et al. (1987) for the delineation of genomic species.

Further DNA-DNA relatedness studies were not carried out between strain SR8.15 $5^{\mathrm{T}}$ and the type strains of related species that shared more than $97 \%$ 16S rRNA gene sequence similarity, such as those of $S$. antimicrobica (97.5\%), S. hirsuta (97.2\%) and S. jiangxiensis (97.3\%), as it has previously been demonstrated that some phylogenetically closely related strains sharing high $16 \mathrm{~S}$ rRNA gene sequence similarity show DNA-DNA relatedness values well below the $70 \%$ cut-off point (Wayne et al., 1987). For example, the type strain of S. jiangxiensis shared 97.5 and $97.4 \% 16 \mathrm{~S}$ rRNA gene sequence similarity with the type strains of $S$. shandongensis and S. spinosa, respectively, but had DNA-DNA relatedness levels of 25.5 and $21.7 \%$, respectively (Zhang et al., 2009).

The results of chemical analysis indicated that strain SR8. $15^{\mathrm{T}}$ has chemotaxonomic markers characteristic of the genus Saccharopolyspora (Korn-Wendisch et al., 1989). It contained meso-diaminopimelic acid in the peptidoglycan and $\mathrm{MK}-9\left(\mathrm{H}_{4}\right)$ as the main menaquinone. Arabinose and galactose were detected as the major components of sugars in whole-cell hydrolysates. Polar lipid analysis showed that the organism contained phosphatidylcholine, phosphatidylglycerol and phosphatidylinositol. No mycolic acids were detected. The $\mathrm{G}+\mathrm{C}$ content of the DNA of strain SR8.15 ${ }^{\mathrm{T}}$ was $70.3 \mathrm{~mol} \%$.

The predominant fatty acids of strain SR8.15 ${ }^{\mathrm{T}}$ were iso$\mathrm{C}_{16: 0} \quad(43.7 \%)$, 10-methyl $\mathrm{C}_{17: 0} \quad(11.8 \%)$, iso- $\mathrm{C}_{17: 0}$ $(8.3 \%)$, iso- $\mathrm{C}_{16: 0} 2-\mathrm{OH}(7.9 \%)$, iso- $\mathrm{C}_{15: 0}(7.5 \%)$ and $9-$ methyl $\mathrm{C}_{16: 0}(5.9 \%)$; other cellular fatty acids detected as minor components were 10-methyl $\mathrm{C}_{18: 0}(4 \%)$, anteiso$\mathrm{C}_{17: 0}(4 \%), \mathrm{C}_{16: 1} 2-\mathrm{OH}(2.5 \%), \mathrm{C}_{17: 1}$ cis 9 (1.9\%), iso$\mathrm{C}_{14: 0}(1.4 \%)$ and $\mathrm{C}_{17: 0}(1.2 \%)$.

The assignment of strain SR8.15 ${ }^{\mathrm{T}}$ to the genus Saccharopolyspora was supported by biochemical, chemotaxonomic, morphological and physiological characteristics. Strain SR8.15 ${ }^{\mathrm{T}}$ was positive for catalase, hydrogen sulfide production and urease. The temperature range for growth was determined in a temperature gradient incubator set to between 5 and $50{ }^{\circ} \mathrm{C}$. Observation of cultures over 14 days revealed growth at $18-42{ }^{\circ} \mathrm{C}$, with the optimum temperature for growth being $28-34{ }^{\circ} \mathrm{C}$. No growth was observed at or above $42{ }^{\circ} \mathrm{C}$. The strain was able to grow at $\mathrm{pH}$ 5.0-9.0, and in the presence of up to $7 \%$ $\mathrm{NaCl}$. Melanin pigment was not produced. Strain SR8.15 was readily differentiated from its closest relatives, $S$. shandongensis and S. spinosa, on the basis of physiological properties (Table 1), in particular the production of allantoinase and nitrate reduction, both of which were negative. These characters were positive in $S$. shandongensis and S. spinosa. Strain SR8.15 $5^{\mathrm{T}}$ produced $\mathrm{H}_{2} \mathrm{~S}$ and was sensitive to $0.005 \%$ lysozyme, whereas $S$. shandongensis gave the opposite results. Strain SR8.15 ${ }^{\mathrm{T}}$ was not able to degrade adenine, arbutin, starch or xanthine, in contrast to results for $S$. shandongensis. Strain $S R 8.15^{\mathrm{T}}$ produced acid from $\mathrm{D}(+)$-galactose, myo-inositol and $\mathrm{D}(+)$-xylose, again contrasting with results for $S$. shandongensis and S. spinosa. Spore arrangement of strain SR8.15 ${ }^{\mathrm{T}}$ was open loops compared with a spiral arrangement in S. shandongensis. Moreover, growth of strain SR8.15 ${ }^{\mathrm{T}}$ occurred between 18 and $42{ }^{\circ} \mathrm{C}$, as compared with $15-38{ }^{\circ} \mathrm{C}$ for S. shandongensis and $15-37{ }^{\circ} \mathrm{C}$ for S. spinosa.

It was evident on the basis of genotypic and phenotypic data that strain SR8.15 $15^{\mathrm{T}}$ can be distinguished from its closest neighbours, S. shandongensis and S. spinosa. We therefore conclude that strain $\mathrm{SR} 8.15^{\mathrm{T}}$ represents a novel 
Table 1. Differential characteristics between strain SR8.15 and the type strains of closely related Saccharopolyspora species

Strains: 1 , SR8.15 ${ }^{\mathrm{T}} ; 2$, S. shandongensis JCM $14614^{\mathrm{T}} ; 3$, S. spinosa JCM $9375^{\mathrm{T}}$. Data are from the present study. + , Positive; - , negative; $\mathrm{W}$, weakly positive.

\begin{tabular}{|c|c|c|c|}
\hline Characteristic & 1 & 2 & 3 \\
\hline Spore arrangement & $\begin{array}{l}\text { Hooks and } \\
\text { open loops }\end{array}$ & Spiral & $\begin{array}{l}\text { Hooks and } \\
\text { open loops }\end{array}$ \\
\hline \multicolumn{4}{|l|}{ Degradation of: } \\
\hline Adenine & - & + & - \\
\hline Aesculin & + & + & - \\
\hline Allantoin & - & + & + \\
\hline Arbutin & - & + & - \\
\hline Starch & - & + & - \\
\hline Xanthine & - & + & - \\
\hline \multicolumn{4}{|l|}{ Acid production from: } \\
\hline $\mathrm{D}(+)$-Cellobiose & - & + & - \\
\hline $\mathrm{D}(+)$-Galactose & + & - & - \\
\hline myo-Inositol & + & - & - \\
\hline Maltose & - & + & - \\
\hline $\mathrm{D}(+)$-Xylose & $\mathrm{w}$ & - & - \\
\hline $\begin{array}{l}\text { Hydrogen sulfide } \\
\text { production }\end{array}$ & + & - & + \\
\hline $\begin{array}{l}\text { Lysozyme resistance } \\
(0.005 \%)\end{array}$ & No growth & Growth & No growth \\
\hline Nitrate reduction & - & + & + \\
\hline $\mathrm{NaCl}$ tolerance $(\%, \mathrm{w} / \mathrm{v})$ & $<7$ & $<7$ & $<11$ \\
\hline Temperature range $\left({ }^{\circ} \mathrm{C}\right)$ & $18-42$ & $15-38$ & $15-37$ \\
\hline
\end{tabular}

species of the genus Saccharopolyspora, for which the name Saccharopolyspora phatthalungensis sp. nov. is proposed.

\section{Description of Saccharopolyspora phatthalungensis sp. nov.}

Saccharopolyspora phatthalungensis (phat.tha.lun.gen'sis. N.L. fem. adj. phatthalungensis referring to Phatthalung Province, Thailand, the source of the rhizosphere soil from which the type strain was isolated).

Aerobic, Gram-positive, non-acid-alcohol-fast, non-motile actinomycete. Cells are filamentous and are differentiated into substrate and aerial mycelium. The aerial mycelium is white, and the substrate mycelium is yellowish to yellowish-brown on ISP media 1, 2, 5, 6 and 7 and GYE agar. A soluble dark-brown pigment is produced on ISP medium 2 but not on ISP media 1, 3, 4, 5, 6 and 7. Spore chains have a bead-like appearance with a spiny spore surface and have an open loop arrangement. Positive for catalase, $\mathrm{H}_{2} \mathrm{~S}$ production and urease. Negative for allantoinase production and nitrate reduction. Acid is produced from adonitol, $\mathrm{D}(-)$-fructose, $\mathrm{D}(+)$-galactose, $\mathrm{D}(+)$ glucose, glycerol, myo-inositol, $\mathrm{D}(-)$-mannitol, $\mathrm{D}(+)$ mannose, $\mathrm{D}(-)$-ribose and $\mathrm{D}(+)$-trehalose, and weakly produced from $\mathrm{D}(+)$-xylose. No acid production from $\mathrm{L}(+)$-arabinose, $\mathrm{D}(+)$-cellobiose, fucose, $\beta$-lactose, malt- ose, melibiose, $\mathrm{D}(-)$-rhamnose, raffinose, $\mathrm{D}(-)$-sorbitol, sorbose, sucrose or xylitol. Degrades aesculin, casein, gelatin, hypoxanthine and L-tyrosine, but not adenine, arbutin, cellulose, chitin, guanine, starch or xanthine. Growth occurs at $\mathrm{pH}$ 5.0-9.0. The temperature range for growth on ISP medium 2 is $18-42{ }^{\circ} \mathrm{C}$ with optimum growth at $28-34{ }^{\circ} \mathrm{C}$. Good growth occurs on ISP medium 2 at $0-5 \% \mathrm{NaCl}$, moderate growth at $6 \% \mathrm{NaCl}$ and poor growth at $7 \% \mathrm{NaCl}$. Alkaline phosphatase and leucine aminopeptidase are detected with the API ZYM enzyme assay; negative for acid phosphatase, chymotrypsin, cystine aminopeptidase, esterase (C4), $\alpha$-fucosidase, $\alpha$-galactosidase, $\beta$-galactosidase, $\alpha$-glucosidase, $\beta$-glucosidase, $\beta$-glucuronidase, lipase (C8), lipase (C14), $\alpha$-mannosidase, $N$ acetyl- $\beta$-glucosaminidase, trypsin phosphoamidase and valine aminopeptidase. The diagnostic diamino acid of the peptidoglycan is meso-diaminopimelic acid. Whole-cell sugars are arabinose and galactose. The glycan moiety of the murein is acetylated. Phospholipids are phosphatidylcholine, phosphatidylglycerol and phosphatidylinositol. The main menaquinone is MK- $9\left(\mathrm{H}_{4}\right)$. Mycolic acids are not detected. The predominant fatty acids are iso- $\mathrm{C}_{16: 0}$, 10-methyl $\mathrm{C}_{17: 0}$, iso- $\mathrm{C}_{17: 0}$, iso- $\mathrm{C}_{16: 0} 2-\mathrm{OH}$, iso- $\mathrm{C}_{15: 0}$ and 9-methyl $\mathrm{C}_{16: 0}$. The $\mathrm{G}+\mathrm{C}$ content of the DNA of the type strain is $70.3 \mathrm{~mol} \%$.

The type strain, SR8.15 ${ }^{\mathrm{T}}\left(=\right.$ TISTR $1921^{\mathrm{T}}=\mathrm{BCC} 35844^{\mathrm{T}}$ $=$ NRRL B-24798 ${ }^{\mathrm{T}}$ ), was isolated from rhizospheric soil of a rubber tree (Hevea brasiliensis), collected from Phatthalung Province, Thailand.

\section{Acknowledgements}

We would like to thank Dr J. P. Euzéby for advice on naming the species, Onsiri Duangchui for providing soil samples and Yuki Inahashi for technical support. This study was supported by the Commission on Higher Education and the Thailand Research Fund, Kasetsart University Research and Development Institute, Faculty of Science at Kasetsart University and Kitasato University.

\section{References}

Becker, B., Lechevalier, M. P. \& Lechevalier, H. A. (1965). Chemical composition of cell-wall preparations from strains of various form-genera of aerobic actinomycetes. Appl Microbiol 13, 236-243.

Collins, M. D., Pirouz, T., Goodfellow, M. \& Minnikin, D. E. (1977). Distribution of menaquinones in actinomycetes and corynebacteria. J Gen Microbiol 100, 221-230.

Duangmal, K., Ward, A. C. \& Goodfellow, M. (2005). Selective isolation of members of the Streptomyces violaceoruber clade from soil. FEMS Microbiol Lett 245, 321-327.

Embley, T. M. (1992). The family Pseudonocardiaceae. In The Prokaryotes, vol. 1, pp. 996-1027. Edited by A. Balows, H. G. Trüper, M. Dworkin, W. Harder \& K. H. Schleifer. Berlin: Springer.

Felsenstein, J. (1985). Confidence limits on phylogenies: an approach using the bootstrap. Evolution 39, 783-791.

Felsenstein, J. (1993). PHYLIP (phylogeny inference package), version 3.5c. Distributed by the author. Department of Genome Sciences, University of Washington, Seattle, USA. 
Fitch, W. M. \& Margoliash, E. (1967). Construction of phylogenetic trees: a method based on mutation distances as estimated from cytochrome $c$ sequences is of general applicability. Science 155, 279284.

Goodfellow, M., Lacey, J., Athalye, M., Embley, T. M. \& Bowen, T. (1989). Saccharopolyspora gregorii and Saccharopolyspora hordei: two new actinomycete species from fodder. J Gen Microbiol 135, 2125-2139.

Gordon, R. E. \& Minm, J. M. (1957). A comparative study of some strains received as nocardiae. J Bacteriol 73, 15-27.

Gordon, R. E., Barnett, D. A., Handerhan, J. E. \& Pang, C. H.-N. (1974). Nocardia coeliaca, Nocardia autotrophica, and the nocardin strain. Int J Syst Bacteriol 24, 54-63.

Hasegawa, T., Takizawa, M. \& Tanida, S. (1983). A rapid analysis for chemical grouping of aerobic actinomycetes. J Gen Appl Microbiol 29, 319-322.

Jacobson, E., Grauville, W. C. \& Fogs, C. E. (1958). Color Harmony Manual, 4th edn. Chicago: Container Corporation of America.

Kieser, Y., Bibb, M. J., Buttner, M. J., Chater, K. F. \& Hopwood, D. A. (2000). Practical Streptomyces Genetics. Norwich: The John Innes Foundation.

Kluge, A. G. \& Farris, J. S. (1969). Quantitative phyletics and the evolution of anurans. Syst Zool 18, 1-32.

Korn-Wendisch, F., Kempf, A., Grund, E., Kroppenstedt, R. M. \& Kutzner, H. J. (1989). Transfer of Faenia rectivirgula Kurup and Agre 1983 to the genus Saccharopolyspora Lacey and Goodfellow 1975, elevation of Saccharopolyspora hirsuta subsp. taberi Labeda 1987 to species level, and emended description of the genus Saccharopolyspora. Int J Syst Bacteriol 39, 430-441.

Küster, E. \& Williams, S. T. (1964). Media for the isolation of streptomycetes: starch casein medium. Nature 202, 928-929.

Labeda, D. P. (1987). Transfer of the type strain of Streptomyces erthyraeus (Waksman 1923) Waksman and Henrici 1948 to the genus Saccharopolyspora Lacey and Goodfellow 1975 as Saccharopolyspora erythraea sp. nov., and designation of a neotype strain for Streptomyces erythraeus. Int J Syst Bacteriol 37, 19-22.

Lacey, J. \& Goodfellow, M. (1975). A novel actinomycete from sugarcane bagasse: Saccharopolyspora hirsuta gen. et sp. nov. J Gen Microbiol 88, 75-85.

Lane, D. J. (1991). 16S/23S rRNA sequencing. In Nucleic Acid Techniques in Bacterial Systematics, pp. 115-175. Edited by E. Stackebrandt \& M. Goodfellow. Chichester: Wiley.

Lu, Z., Liu, Z., Wang, L., Qi, W. \& Goodfellow, M. (2001). Saccharopolyspora flava sp. nov. and Saccharopolyspora thermophila sp. nov., novel actinomycetes from soil. Int J Syst Evol Microbiol 51, 319-325.

Mertz, F. P. \& Yao, R. C. (1990). Saccharopolyspora spinosa sp. nov. isolated from soil collected in a sugar mill rum still. Int J Syst Bacteriol 40, 34-39.

Minnikin, D. E., Patel, P. V., Alshamaony, L. \& Goodfellow, M. (1977). Polar lipid composition in the classification of Nocardia and related bacteria. Int J Syst Bacteriol 27, 104-117.
Page, R. D. M. (1996). TreeView: an application to display phylogenetic trees on personal computers. Comput Appl Biosci 12, 357-358.

Pimentel-Elardo, S. M., Tiro, L. P., Grozdanov, L. \& Hentschel, U. (2008). Saccharopolyspora cebuensis sp. nov., a novel actinomycete isolated from a Philippine sponge (Porifera). Int J Syst Evol Microbiol 58, 628-632.

Saitou, N. \& Nei, M. (1987). The neighbor-joining method: a new method for reconstructing phylogenetic trees. Mol Biol Evol 4, 406425.

Shirling, E. B. \& Gottlieb, D. (1966). Methods for characterization of Streptomyces species. Int J Syst Bacteriol 16, 313-340.

Stackebrandt, E. \& Ebers, J. (2006). Taxonomic parameters revisited: tarnished gold standards. Microbiol Today 33, 152-155.

Tamaoka, J. \& Komagata, K. (1984). Determination of DNA base composition by reversed-phase high-performance liquid chromatography. FEMS Microbiol Lett 25, 125-128.

Tang, S.-K., Wang, Y., Cai, M., Zhi, X.-Y., Lou, K., Xu, L.-H., Jiang, C.-L. \& Li, W.-J. (2009). Saccharopolyspora halophila sp. nov., a novel halophilic actinomycete isolated from a saline lake in China. Int J Syst Evol Microbiol 59, 555-558.

Thompson, J. D., Gibson, T. J., Plewniak, F., Jeanmougin, F. \& Higgins, D. G. (1997). The CLUSTAL_X windows interface: flexible strategies for multiple sequence alignment aided by quality analysis tools. Nucleic Acids Res 25, 4876-4882.

Tomiyasu, I. (1982). Mycolic acid composition and thermally adaptative changes in Nocardia asteroides. J Bacteriol 151, 828-837.

Uchida, K. \& Aida, K. (1984). An improved method for the glycolate test for simple identification of acyl type of bacterial cell walls. J Gen Appl Microbiol 30, 131-134.

Wayne, L. G., Brenner, D. J., Colwell, R. R., Grimont, P. A. D., Kandler, O., Krichevsky, M. I., Moore, L. H., Moore, W. E. C., Murray, R. G. E. \& other authors (1987). International Committee on Systematic Bacteriology. Report of the ad hoc committee on reconciliation of approaches to bacterial systematics. Int J Syst Bacteriol 37, 463-464.

Yassin, A. F. (2009). Saccharopolyspora rosea sp. nov., isolated from a patient with bronchial carcinoma. Int J Syst Evol Microbiol 59, 11481152.

Yuan, L.-J., Zhang, Y.-Q., Guan, Y., Wei, Y.-Z., Li, Q.-P., Yu, L.-Y., Li, W.-J. \& Zhang, Y.-O. (2008). Saccharopolyspora antimicrobica sp. nov., an actinomycete from soil. Int J Syst Evol Microbiol 58, 1180-1185.

Zhang, J., Wu, D., Zhang, J., Liu, Z. \& Song, F. (2008). Saccharopolyspora shandongensis sp. nov., isolated from wheat-field soil. Int J Syst Evol Microbiol 58, 1094-1099.

Zhang, J., Wu, D. \& Liu, Z. (2009). Saccharopolyspora jiangxiensis sp. nov., isolated from grass-field soil. Int J Syst Evol Microbiol 59, 10761081.

Zhou, Z. H., Liu, Z. H., Qian, Y. D., Kim, S. B. \& Goodfellow, M. (1998). Saccharopolyspora spinosporotrichia sp. nov., a novel actinomycete from soil. Int J Syst Bacteriol 48, 53-58. 